\title{
The "Quantitative Discretion Index": A New Business Ethics Tool to Prevent Opportunistic Earnings Management Practices
}

\author{
Damiano Montani ${ }^{1}$, Francesco Perrini ${ }^{2}$, Daniele Gervasio ${ }^{1} \&$ Andrea Pulcini $^{1}$ \\ ${ }^{1}$ University of Bergamo, Bergamo, Italy \\ ${ }^{2}$ Bocconi University, Milano, Italy \\ Correspondence: Damiano Montani, University of Bergamo, Bergamo, Italy. E-mail: damiano.montani@unibg.it
}

Received: February 19, $2020 \quad$ Accepted: March 28, $2020 \quad$ Online Published: April 6, 2020

doi:10.5539/jms.v10n1p96 URL: https://doi.org/10.5539/jms.v10n1p96

\begin{abstract}
In this article, we build a Quantitative Discretion Index (hereafter referred to as QDI) to identify within the financial statements the most vulnerable areas related to possible opportunistic earnings management (hereafter referred to as EM) practices, with the aim of supporting ethical behaviour in corporate social communications. In order to better explain the QDI construction method, a practical example is implemented, starting from an analysis of the consolidated balance sheet of an Italian listed company operating in the media sector (in 2016).
\end{abstract}

The QDI might be added to the contents of voluntary information provided by companies that pay attention to ethical behaviour and corporate social responsibility.

Within each corporate balance sheet, the QDI allows stakeholders to identify the evaluation discretion areas, where any possible EM practices may be more likely and on which it may be more useful for stakeholders to focus their research attention.

Business ethics aims to mitigate EM practices in social communications, including voluntary communication. Indeed, the discretional nature of the assessment of financial statements items by the administrative body represents one of the main weaknesses in the activity of mitigating earnings management practices.

At present, the literature has dealt with the relations between ethical behaviour and EM; however, the research should also provide tools that can identify and neutralise the possibilities that opportunistic EM practices can be implemented, thus resulting in more ethical business practices.

Keywords: agency theory, business ethics, disclosure reporting, earnings management, ethical behaviour, matrix format, responsible manager

\section{Introduction}

In this study, we aim to improve the quality of voluntary corporate information, with particular reference to the financial statements.

During recent years, in the continuous improvement of financial reporting, the literature has focused on aspects related to the adoption of the principles of ethical behaviour and corporate social responsibility in companies, highlighting the benefits related to the quality of social communications (Dhaliwal et al., 2011; Martínez-Ferrero et al., 2015; Gong et al., 2018). A corporate culture based on ethical behaviour may contribute to the integrity of the financial reporting process (Beaudoin et al., 2015).

Across different countries, some empirical cases show that a high level of quality in corporate disclosure appears to be crucial to deal with managerial malpractices and the manipulations of earnings (Katmon \& Farooque, 2017).

The goals of business ethics include the facilitation of the correctness of social communications and the minimisation of opportunistic earnings management (EM) practices in the financial statements (Martínez-Ferrero et al., 2016): while in the past financial statement disclosure was considered an issue of interest only for shareholders (Friedman, 1970), currently, the "stakeholder theory" (Freeman, 1984; Freeman, 1994; Freeman et al., 2010) has highlighted how for all stakeholders of a company, balance sheet disclosure has become so significant that the improvement of financial disclosure is in effect a form of the "socially responsible behaviour" of managers (Gelb \& Strawser, 2001). 
The connection between ethical practices, corporate social responsibility and EM has been identified and analysed by Chih et al. (2008); Greenfield et al. (2008) suggest a significant relationship between the individual's ethical orientation and earnings management practices. This last study was deepened and extended by Johnson et al. (2011) and by Shafer (2015). Hong and Andersen (2011) analysed the interrelation between ethics, corporate social responsibility, earnings management and financial statement quality, highlighting the direct correlation between a higher level of ethics and a lower application of opportunistic earnings management strategies by companies but pointing however to the need to identify operational tools to achieve these results.

However, while ethical behaviour aims to minimise the engagement in opportunistic EM activities in the preparation of financial statements, the scientific literature has highlighted the conditions that can allow the establishment of abuses in the presence of the normal discretionary evaluative capability granted to managers based on the standards for the evaluation of balance sheet items.

In fact, the relationship between evaluative discretion and balance sheet quality has been analysed in numerous studies: in particular, the theory of agency (Jensens \& Meckling, 1976; Fama, 1980) and the theory of earnings management. The latter investigates the use of discretion by managers in an opportunistic manner (Burgstahler \& Dichev, 1997; Burgstahler \& Eames, 2006) or in order to manage the dissemination of information of which only they are in possession (Watts \& Zimmerman, 1986; Holthausen, 1990; Altamuro et al., 2005).

The combination of the afore-mentioned theories leads to the following consequences (Figure 1):

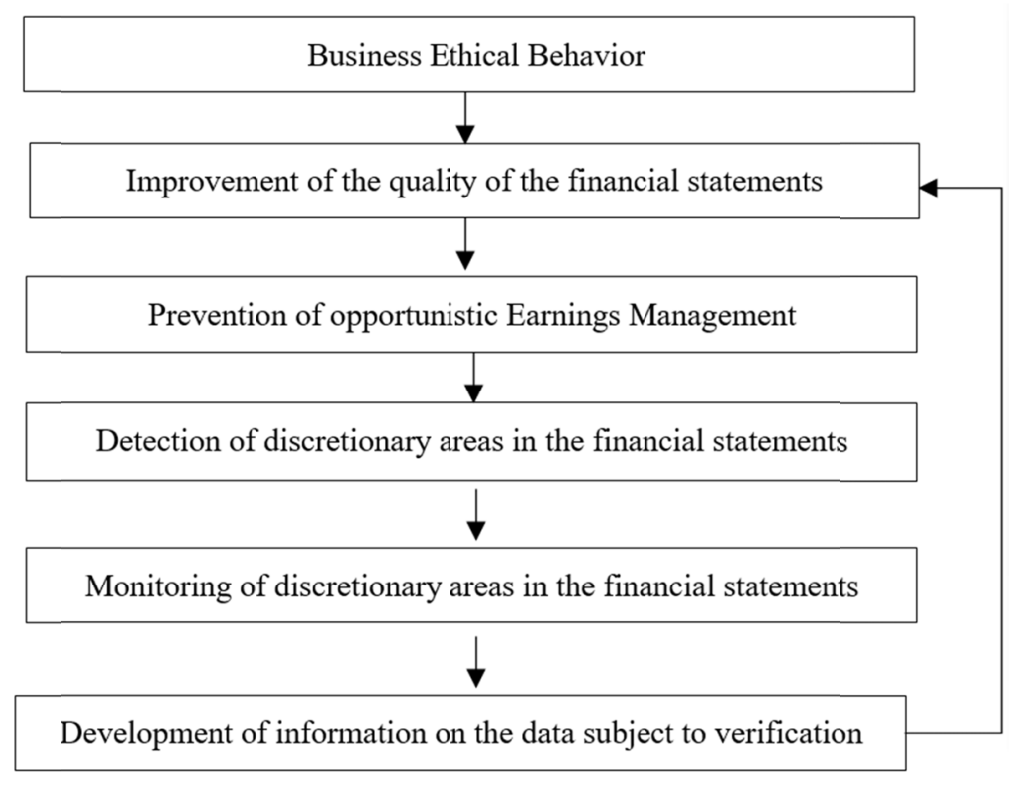

Figure 1. Cycle to contrast opportunistic earnings management

EM practices can be implemented in the presence of evaluative discretion, as will be seen below: in fact, in the assessment of financial statement items, the more discretion managers have, the greater the possibility of their implementation of an opportunistic EM practice, especially when the information used is in their sole possession. For companies wishing to invest in ethical behaviour, it is useful to increase the provision of voluntary information, such as the index of discretion provided in this work: this indicator will enable the identification of the balance sheet items most characterised by evaluative discretion and facilitate the monitoring of the companies' management, according to the procedure described above. The indicator, called the Quantitative Discretion Index (QDI) can have a value between 1 and 5, where 1 is the minimum discretion level adopted by management in evaluating the financial statement item and 5 is the maximum discretion level. Therefore, if the indicator (calculated for both assets and liabilities in the balance sheet) is close to 5, it means that the data shown in the financial statements are mostly the result of discretional assessments made by management and, therefore, could possibly be influenced by EM practices. Otherwise, the more the index of each accounting item approaches 1, the greater the probability that it has not been subjected to any EM interference by the managers, unless the managers are aggressively engaged in EM practices, close to committing accounting fraud or even 
engaged in a morally reprehensible lobbying effort against the accounting regulator (Gowthorpe \& Amat, 2005). The QDI can be defined as a weighted average that is determined by considering the level of discretion attributed to each balance sheet item and the amount of that same item in the budget. Inspired by the concept of "Matrix Format financial statement" studied by Tarca et al. (2007 and 2008), a modality will be presented to show the accounting data "matrix format" that can express the very relevant information concerning the discretionary nature of the valuation of financial statement items. In this way, due to the dissemination of impartial information, the financial statements become effective support elements for stakeholders for decision-making and ultimately, through the correct use of fair value, performance statements, and information regarding risks and uncertainties, the financial statements contribute to the prosperity of the company; the assessment of the extent of EM practices is thus facilitated by annual financial statements providing more information than is required by the current ones (Barth, 2018).

\section{Literature Review}

\subsection{Corporate Social Responsibility, Quality of Information and Voluntary Information in the Financial Statements of Companies}

Originally, the "shareholder theory" identified the maximisation of profits as the sole objective of the company (Friedman, 1970): therefore, disclosure was considered an element of interest only for shareholders.

The birth of the stakeholder theory (Freeman, 1984; Freeman, 1994) and its dissemination (Freeman et al., 2010) in the corporate world (Harrison \& Wicks, 2013) has instead highlighted how the company must pay attention to the needs of the various stakeholders (Carroll \& Buchholtz, 2014): it follows that the disclosure presented in the financial statements is an element of interest for all those who are directly or indirectly linked to the company. Even the standard setters have made this new vision their own: to enable information recipients to make consistent decisions, the International Accounting Standards Board (IASB) finalises financial statements to a wide range of users (IASB, 2012).

To better explain the information contained in disclosures sent to recipients, the Financial Accounting Standards Board (FASB) is currently working on a project aimed at improving the quality and efficiency of financial disclosures (FASB, 2017).

Stakeholder theory has not only influenced the improvement of the quality of financial information but has also pushed many companies to provide voluntary disclosures on their social responsibility practices (Dhaliwal et al., 2011) in addition to the information they provide based on the minimum legal requirements (McWilliams \& Siegel, 2001).

Increasingly, the notes to the financial statements of companies (or even specific reports) report information on the status of their "ethical" initiatives, such as the protection of the environment, programmes to support the local community or human rights' endeavours (Deegan \& Gordon, 1996; Hooghiemstra, 2000; Kolk, 2003; Mahadeo et al., 2011; Alberici \& Querci, 2016).

Trying to understand the quality and impact on the economic performance of companies (Stanwick \& Stanwick, 1998; Orlitzky et al., 2003; Platonova et al., 2018), on the cost of capital (Reverte, 2012; Dhaliwal et al., 2014) and on company value (Lima Crisóstomo et al., 2011), the academic literature has therefore focused on the analysis of financial statement information that is different from economic-financial data.

However, the credibility of such information is nevertheless based on the financial statement's economic, equity and financial data, which offers a complete, clear and correct view of the company's reality. Gelb and Strawser (2001) affirm that the improvement of disclosure has become a form of "socially responsible" behaviour for managers, who cannot ignore the increased importance of the quality of corporate financial and economic information.

\subsection{The Discretionary Nature of the Financial Statements: Agency Theory and Earnings Management}

Some of the first studies dealing with the potential problem of evaluative discretion focused on the agency theory (Ross, 1973; Heckerman, 1975; Jensens \& Meckling, 1976; Fama, 1980). The agency model is defined by Jensens and Meckling (1976) as a contract according to which one or more persons (principal) obliges another person (agent) to cover a given task on his behalf, which implies a delegation of power to the agent. The central element of the agency theory is the potential divergence of interests between the principal and the agent (Dalton et al., 2007) and how this divergence could encourage the latter to use the autonomy granted and the information asymmetries available to pursue their own objectives, different and/or contrasting with those of the principal. The latter, to try to limit this inconvenience, is forced to incur costs (agency costs) to monitor the agent's activity and to "realign" the interests of the agent to his own (Martin et al., 2016). From the definition of an agency 
model, it is very intuitive to understand how it is frequently found in the dynamics that characterise corporate life: the owners of the company (shareholders) are the "principals", while the managers, who are given the management power (also information and social communications responsibility), are the "agents". Considering both the stakeholder theory and the agency theory, Hill and Jones (1992) and Shankman (1999) then highlighted how the "principal-agent" model does not concern only the shareholders and managers but all the stakeholders in the company and the managers. Several studies have been conducted with the aim of understanding the implications that agency theory could have on disciplines, such as organisational behaviour, organisational theory, strategic management and corporate governance (Eisenhardt, 1985, 1988, 1989; Pepper \& Gore, 2015; Bosse \& Phillips, 2016; Shi et al., 2017). The problem of the principal-agent model may also involve the preparation of the financial statements (Jiraporn et al., 2008; Ramanna, 2008): to understand the real equity, economic and financial situation underlying the enterprise, the stakeholders are interested in having clear, truthful and correct information; on the contrary, managers might have a conflicting interest, especially - as the agency theory predicts - when financial statement data are not positive or are not congenial to their personal interests and when the managers' activities are assessed on the basis of performance resulting from the financial statement. The managers have asymmetries of information and at the same time have great discretionary assessment in the preparation of the financial statement: in light of the agency theory, managers could then abuse the discretion granted them and could alter for their personal interest the disclosure of financial statements (Leuz et al., 2003), triggering the behaviour called earnings management, also referred to as "information management" (Schipper, 1989). Healy and Wahlen (1999) find an EM phenomenon "when managers use judgement in financial reporting and in structuring transactions to alter financial reports to either mislead some stakeholders about the underlying economic performance of the company or to influence contractual outcomes that depend on reported accounting numbers". Numerous studies have shown how the discretion granted to managers in drafting the balance sheet can be used by them in an opportunistic way (Burgstahler \& Dichev, 1997; Burgstahler \& Eames, 2006). The interests that can push managers to alter the disclosure of financial statements are different and include the following reasons: to increase the level of income (pay for performance) to obtain bonuses linked to the company's income performance (Healy, 1985; Guidry et al., 1999; Detzen \& Zulch, 2012; Li \& Kuo, 2017; Guthrie et al., 2017); to implement income smoothing policies (Gaver et al., 1995; Bhattacharya et al., 2003; Das et al., 2013; Khurana et al., 2017); to favour the overcoming of a fixed income target (the so-called threshold mentality) for the enhancement of the corporate image and the avoidance of negative repercussions in the behaviour of the stakeholders (Degeorge et al., 1999; Mindak, 2016; Bonacchi et al., 2017); and to proceed with policies called "big baths", typically found when new accounting standards are adopted (Jordan \& Clark, 2003; Bens \& Heltzer, 2005; Lapointe et al., 2008) or when there is a turnover in management (Nieken \& Sliwka, 2015). Therefore, the moral issue related to EM is important: for Elias (2002), the contrasting opinions on EM stem from the combination of business ethics, moral philosophies and social responsibility. Individuals who believe in ethical behaviour and long-term gains rate EM as reflecting more unethical behaviour, while individuals who believe in short-term gains rate EM as ethical behaviour; these findings suggest if the objective is to reduce the occurrence of earnings management, attention should be paid to the individual's moral philosophy and the related timeframe.

However, positions on the subject of EM and on the use of the flexibility granted to managers in the preparation of the financial statements are not unambiguous. In contrast to the aforementioned studies, there are some that have shown how the discretion left to managers in preparing the financial statements can potentially improve disclosure since taking advantage of the discernment that accounting principles grant, managers can communicate to stakeholders "private" information that only they possess internally and that provides a better representation of the company's reality (Watts \& Zimmerman, 1986; Holthausen, 1990; Healy \& Palepu, 1993; Guay et al., 1996; Subramanyam, 1996; Demski, 1998; Arya et al., 2003; Kanagaretnam et al., 2005; Altamuro et al., 2005; Badertscher et al., 2012; Allen et al., 2013; Jin et al., 2016). The IASB, in adopting this vision, has also envisaged accounting practices based on broad evaluative discretion: consider the adoption of the fair value criterion (IFRS 13) or the impairment test (IAS 36).

The valuation discretion granted to a manager in the preparation of the financial statement can therefore also have a heavy impact on the quality of the information, both in positive and negative terms, and the scientific debate has not reached a unanimous conclusion on the value of attributing such discretion to a group of subjects that could benefit personally from the use of this position.

\section{Theorethical Framework}

\subsection{Identification of Evaluative Discretion and Earnings Management Phenomena}

The use or, in the case of opportunistic EM, the abuse of evaluative discretion by managers in the financial 
statements of companies has long been the subject of investigation in the literature and a research objective.

The pioneer in this area was Healy (1985), who examined the discretion adopted by managers in determining discretionary accruals and analysed the relationship between discretionary accruals' determination and the bonuses that directors can receive when the income performance exceeds a certain level.

Focusing on the discretion of managers in quantifying discretionary provisions, De Angelo (1986) takes up the Healy model (1985). McNichols and Wilson (1988) check whether the discretion used by managers in determining a specific provision (the allowance for bad debts) determines their possible manipulation of income.

Unlike the two models previously mentioned, McNichols and Wilson's (1988) model is characterised by the use of the event-study approach (Dolley, 1933; Fama et al., 1969; Binder, 1998). This approach was also used in the Jones (1991) model, which, unlike the McNichols \& Wilson model, studies the relationship between the discretion adopted by managers in determining all discretionary provisions (not only a specific provision) and the manipulation of income.

Conducting a test to verify 13 potential critical points for EM, Merchant and Rockness (1994) provide a further contribution.

The Jones model is taken up and improved by the work of Dechow et al. (1995), who elaborate the model known as the "Modified Jones Model".

Used to study the discretion and manipulation of profits through regression models, statistical tests and event-study approaches, the models presented so far are also known as "first generation models".

Their evolution is represented by "second generation models", which can be traced, in particular, to the studies carried out by McNichols (2002) and by Kothari et al. (2005).

Finally, among the latest studies aimed at investigating the use of discretion by managers and the possible phenomena of earnings management, there is the study by Dechow et al. (2012). Based on these experiences, Vladu et al. (2017) have identified a series of financial statement ratios that can enable the identification of any EM phenomena by managers (or, in general, by those who are able to use their dominant position in order to adapt the budget results to their own personal purposes). This model, although paving the way for new research questions, seems more aimed at a statistical identification of the elements particularly subject to EM practices in the financial statement.

Other authors (Beaudoin et al., 2015), with the aim of mitigating the implementation of EM practices in the company's financial statements, conducted an experiment to verify the management of discretionary expense accruals by some CFOs. Between EM practices and corporate risk-taking practices, Frank et al. (2018) have found a correlation only partially mitigated after the advent of SOX.

In summary, the scientific literature now offers more experimental methods to primarily statistically identify the presence of EM practices but does not provide new information on tools that could be provided to stakeholders through integration into financial disclosures.

The following is intended to provide additional support for monitoring EM through voluntary supplementary information, which managers should be required to provide together with the financial statement.

\subsection{Using the "Matrix Format" Financial Statement to Build the "Quantitative Discretion Index" (QDI)}

From the hints mentioned so far, we understand that the literature has now established the dangers of EM and the usefulness of fostering corporate business ethics practices to fight opportunistic EM.

The scientific contributions so far have focused on how to statistically identify or quantify the EM phenomena.

However, for understanding the level of discretion applicable to each financial statement item, we propose the provision of additional information in the form of an index, which, if voluntarily published in the notes to the financial statements, can provide valid support to the stakeholders. As will be seen, a peculiar aspect of the Quantitative Discretion Index (QDI) is the representation of the balance sheet data in a "matrix" form.

The idea of structuring the balance sheet data in this way is not completely new and takes its cue from the "matrix format" statement project, the result of a joint work of the IASB $(2001,2003)$ and the UK Accounting Standards Board (Standards Advisory Council, 2006) on performance reporting.

Other scholars have also been interested in this way of presenting the balance sheet data (Barker, 2004), examining how to ensure through the representation of revenues and operating costs that the receivers of the financial statements have a full and correct understanding of the company's performance. 
The new format of the financial statements, representing an evolution of the "comprehensive income" statement envisaged in the IAS/IFRS principles, is capable of simultaneously meeting the information needs of the stakeholders oriented to the static valuation methods (related to the principle of prudence and historical cost) and the needs of the other operators interested in the results of the dynamic valuations (mostly related to the fair value determinations) (IAS plus, 2006).

Initially, the proposal for the presentation of balance sheet data with a matrix was examined in the international literature only for data of an economic nature (Tarca et al., 2007; Tarca et al., 2008) and was subsequently examined in the literature for data related to assets and liabilities (Gervasio \& Montani, 2013).

The "matrix format" balance sheet is so called because it is characterised by the presence of three columns where each financial statement item is placed through the following format (Table 1):

- An initial column expresses the value deriving from accounting entries, that is, the result of static evaluation criteria.

- A second column is dedicated to "re-measurement", i.e., those changes (increasing or decreasing) that adjust the value reported in the first column to the value recalculated on the basis of a dynamic valuation criteria: in this way, it separates and highlights the part characterised by a conjectural nature and that is referred to as prospective or as potential.

- A third column indicates the total value of the asset estimated at fair value and is equal to the sum of historical and potential/prospective capital components described in the first two columns.

Table 1. "Matrix Format" balance sheet structure (Gervasio \& Montani, 2013)

\begin{tabular}{llll}
\hline Description of Assets/Liabilities & Historical Value (a) & Remeasurement (b) & Dynamic Values (a+b) \\
\hline $\begin{array}{l}\text { Balance Sheet Items (property, plant, equipments, } \\
\text { inventories, commercial loans...) }\end{array}$ & $\ldots$ & $\ldots$ & $\ldots$ \\
Total Assets/Liabilities & $\ldots$ & $\ldots$ & $\ldots$ \\
\hline
\end{tabular}

This proposal, too early for the period in which it was presented, has never materialised in the International Accounting Standards and was abandoned because it was considered too complex, even though Tarca et al. (2008) have shown that the "Matrix Format" does not increase the difficulty of reclassification and interpretation of data but, on the contrary, gives new and very useful information.

The matrix format is useful to facilitate the understanding and reading of financial statement data, including the balance sheet and is especially useful for the construction of the QDI.

Specifically, we propose the use of a balance sheet with 5-columns, in which each column corresponds to the "levels" of discretion used for the determination of the QDI (Table 2).

Table 2. Synthesis levels of discretion for construction QDI

\begin{tabular}{ll}
\hline Level of Discretion & Description \\
\hline 1 & The determination of the value does not require any subjective evaluation by the managers \\
2 & Valuations done based on historical cost or amortised cost (if not subject to permanent losses of value or revaluations) \\
& or inventories valued at the weighted average cost or FIFO \\
3 & Fair value - first level inputs (according to those envisaged by IFRS 13) \\
4 & Fair value - second level inputs (according to those envisaged by IFRS 13) \\
5 & Fair value - third level inputs (according to those envisaged by IFRS 13) \\
\hline
\end{tabular}

To choose the column in which to enter each item in the financial statement (and then assign the item a level of discretion from 1 to 5), an analysis of the accounting information is necessary to understand the evaluation criterion adopted for the specific item. The division of the balance sheet into 5 columns, as well as being functional for the calculation of the QDI, also visually allows the identification of the balance sheet items characterised by a greater or less evaluative discretion adopted by the managers.

As a summary of the evaluative discretion, we proceed as follows to the calculation of the QDI, which summarises with a single number the subjectivity level of assets or liabilities.

- The closer to 1 the value of the QDI is, the more the balance sheet is "objective", i.e., the amount of 
discretion used by managers in the assessment of the balance sheet items is low.

- The closer to 5 the value of the QDI is, the more the balance sheet data represents the result of evaluations by the management and consistent with the analysis of agency theory and the phenomena of opportunistic EM, the more the potential underlying problems.

For each financial statement, two QDI will be calculated: one for the assets $\left(\mathrm{QDI}_{\mathrm{a}}\right)$ and one for the liabilities $\left(\mathrm{QDI}_{1}\right)$.

The construction of the index relating to the asset side of the balance sheet is based on a simple weighted average, which is calculated by the following formula:

$$
Q D I_{a}=\sum_{1}^{n} \frac{D L_{n} * B S I_{n}}{T A}
$$

where the variables are defined as follows:

- $\quad \mathrm{QDI}_{\mathrm{a}}$ denotes the Quantitative Discretion Index relative to the asset side.

- $\quad \mathrm{DL}_{\mathrm{n}}$ denotes the discretion level attributed to the item " $\mathrm{n}$ ". Based on the level of discretion attributed to the " $\mathrm{n}$ " financial statement item, it will therefore be a numerical value between 1 and 5 (for example, if the balance sheet item has been included in column 2, i.e., assigned a level 2 of discretion, then the DL relative to that specific balance sheet item will be equal to 2 ).

- $\quad \mathrm{BSI}_{\mathrm{n}}$ denotes balance sheet items, i.e., the value shown in the balance sheet under the item " $n$ ".

- TA denotes total assets, i.e., the sum of the items included in the asset side of the balance sheet.

In addition, the construction of the index relating to the liability side of the balance sheet is based on a weighted average, as evidenced by the following formula:

$$
Q D I_{l}=\sum_{1}^{n} \frac{D L_{n} * B S I_{n}}{T L}
$$

where the variables are defined as follows.

- $\quad \mathrm{QDI}_{1}$ denotes the Quantitative Discretion Index relating to the liability side.

- $\mathrm{DL}_{\mathrm{n}}$ denotes the discretion level attributed to the balance sheet item "n". Based on the level of discretion attributed to the " $n$ " budget item, it will therefore be a numerical value between 1 and 5 (for example, if the "n" balance sheet item has been entered in the 2, i.e., entered in the level 2 discretionary column, then the DL of the balance sheet item " $n$ " will be 2).

- $\mathrm{BSI}_{n}$ denotes balance sheet items, i.e., the value shown in the balance sheet under the item " $n$ ".

- $\quad$ TL denotes total liabilities, i.e., the sum of liabilities in the balance sheet (net of shareholders' equity).

The QDI is characterised by a great simplicity of calculation and intuitiveness. A high level of QDI does not imply a fraudulent balance sheet but a budget with extremely volatile items: for example, a QDI close to 5 means that the data expressed in the financial statements are exclusively the result of presumptions and that therefore they may vary considerably (positively or negatively) when the assumptions underlying the evaluations no longer apply.

\section{Method}

\subsection{The Quantitative Discretion Index (QDI): An Italian Case Study}

The following is a case study to show the application of the QDI.

The case study is based on the analysis of the consolidated balance sheet of an Italian listed company operating in the media sector (in 2016) and adopting IAS/IFRS.

Below is the balance sheet format based on the calculation of the QDI for assets (Table 3) and for the liabilities (Table 4).

The last column of Tables 3 and 4, called "Notes", is added in order to present, for each balance sheet item, a brief explanation of the reasons behind the levels of discretion attributed and it helps to better understand the QDI construction method. 
In the penultimate row of tables, we express, in percentage terms, the "weight" of each level of discretion. Finally, in the last row, the QDI is shown.

Table 3. Determination of QDI assets - Consolidated Financial Statements 2016 (data in millions of euros)

\begin{tabular}{|c|c|c|c|c|c|c|c|}
\hline \multirow[t]{2}{*}{ ASSETS DESCRIPTION } & \multicolumn{5}{|c|}{ LEVELS OF DISCRETION } & \multirow[t]{2}{*}{ TOTAL } & \multirow[t]{2}{*}{ Notes } \\
\hline & 1 & 2 & 3 & 4 & 5 & & \\
\hline \multicolumn{8}{|l|}{ NON-CURRENT ASSETS } \\
\hline Property, plant and machinery & & 445.7 & & & & 445.7 & (1) \\
\hline Television and film rights & & & & $1,629.7$ & & $1,629.7$ & (2) \\
\hline Goodwill & & & & 820 & 144.7 & 964.7 & (3) \\
\hline Other intangible assets & & 850.7 & & & & 850.7 & (4) \\
\hline Investments in associates/jointly controlled companies & & 47.3 & & & & 47.3 & (5) \\
\hline Other financial assets & & 13.2 & & 48 & & 61.2 & (6) \\
\hline Deferred tax assets & & & & & 518.3 & 518.3 & (7) \\
\hline TOTAL NON-CURRENT ASSETS & & & & & & $4,517.8$ & \\
\hline \multicolumn{8}{|l|}{ CURRENT ASSETS } \\
\hline Inventories & & 33 & & & & 33 & (8) \\
\hline Commercial credits & & 1,258 & & & & 1,258 & (9) \\
\hline Tax credits & & 53.3 & & & & 53.3 & (10) \\
\hline Other receivables and current assets & & 288.8 & & & & 288.8 & (11) \\
\hline Current financial assets & & 29.3 & & 9.8 & 16.2 & 55.2 & (12) \\
\hline Cash and cash equivalents & 328.8 & & & & & 328.8 & (13) \\
\hline TOTAL CURRENT ASSETS & & & & & & $2,017.1$ & \\
\hline TOTAL ASSETS & & & & & & $6,534.9$ & \\
\hline$\%$ Level of discretion of the total & $5.03 \%$ & $46.20 \%$ & $0.00 \%$ & $38.37 \%$ & $10.39 \%$ & $100 \%$ & \\
\hline$Q D I_{a}$ & 3.03 & & & & & & \\
\hline
\end{tabular}

(1) "Property, plant and equipment" has been assigned a level of discretion of 2. In fact, in the explanatory note, it is specified that property, plant and equipment are recorded at purchase or production or transfer cost, including any accessory charges, any dismantling costs and the direct costs necessary to make the asset available for use.

(2) "Television and film rights" have been assigned a level of discretion of 4 . In the explanatory notes, it is specified that intangible assets with a finite useful life (including television and film rights) are systematically amortised from the moment in which the asset is available for use for the period of its expected usefulness; the recovery of their value is verified according to the criteria set forth in IAS 36. These items were subject to significant impairment losses. In consideration of the non-financial nature of the assets being valued and the specifics of the markets in which they are traded, reference was made to the inputs included in the hierarchy envisaged by IFRS 13 level 2 (different observable inputs from quoted prices), integrated with level 3 (internally processed data and company estimates as well as forecasts derived from external sources).

(3) The total of the goodwill item was split into two columns of the balance sheet. The goodwill attributed to 3 CGUs (Cash Generating Units) with a total value of 820 million euros was assigned a level of discretion equal to 4; the explanatory note in fact explains that such goodwill is confirmed by the values expressed by the stock market capitalisation on the measurement date (different observable inputs from quoted prices). Goodwill with a value of 144.7 has been assigned a level of discretion of 5 .

(4) The item "Other intangible assets" includes the following items:

- Industrial patent rights and the use of intellectual property have a value of 21.8; the level of discretion assigned is 2 since the valuation is made at historical cost, net of systematic amortisation.

- Trademarks are valued at 155.1; the level of discretion assigned is 2 since the valuation is made at historical cost, net of systematic amortisation.

- Concessions are valued at 382; the level of discretion assigned is 2, as the valuation is made at historical cost, net of systematic amortisation. Some concessions have been subjected to an impairment test; the test confirmed the correctness of the accounting values entered in the financial statements.

- Contract portfolios and customers are valued at 168.1; the level of discretion assigned is 2, as the valuation is made at historical cost, net of systematic amortisation. 
- Intangible assets in progress and advances are valued at 123.1; the level of discretion assigned is 2 since these are advances paid to suppliers for the purchase of rights, advances on dubbing. These are therefore items characterised by a low level of discretion in the assessment.

- Other intangible assets are valued at 0.5 ; due to the low value of this item, there is no information given in the explanatory note. In line with the level of discretion attributed to the other elements included in the item "Other intangible assets", the level of discretion that has been assigned is 2.

(5) The item "Investments in associates/joint ventures" was assigned a level of discretion of 2 since this item is accounted for in the consolidated financial statements by applying the equity method.

(6) The item "Other financial assets", which represents investments in other companies in an amount equal to 32.2 , has been assigned a level of discretion of 4 , as the explanatory note states that the fair value is determined on the basis of specific valuation models or by taking into account the prices of recent transactions involving the capital of these companies. Other financial assets also include financial receivables for an amount equal to 13.2: the level of discretion assigned is equal to 2, as they are valued at amortised cost. Finally, the item "Other financial assets", an amount equal to 15.8, also includes derivative instruments designated as hedging. The level of discretion attributed to this item is 4 . This choice is justified by the fact that in the explanatory note, we speak of derivative instruments to hedge the exchange risk: it is assumed that the essential data for the purpose of estimating the value are inputs observable on the market, in particular, exchange rates.

(7) The item "Deferred tax assets" has been assigned a level of discretion of 5 because accounting for deferred tax assets is made on the basis of expected taxable income expected in future years. Since these are assessments based on internal company data, it was considered appropriate to assign the highest level of discretion.

(8) "Inventories" have been assigned a level of discretion of 2 . This choice is justified by the fact that inventories of raw materials, semi-finished and finished products are valued at the lower of purchase or production cost, including charges for accessories (FIFO method) and the net presumable realisable value inferable from the market trend.

(9) The item "Commercial credits" has been assigned a level of discretion of 2, as they are valued at their nominal value.

(10) The item "Tax credits" has been assigned a level of discretion of 2 . These are net tax positions that the Group has towards the tax authorities.

(11) The item "Other receivables and current assets" has been assigned a level of discretion of 2. This item includes receivables from others for a total of $€ 166.8$ and accrued income and prepaid expenses for an amount equal to $€ 122.1$.

(12) The item "Current financial assets" consists of several elements:

- Current financial receivables are valued at 29.3 and have been assigned a level of discretion of 2.

- Securities and current financial assets referable to bonds have a value of 9.8. A level of discretion of 4 was assigned.

- Financial assets for designated derivatives hedging are valued at 9.9 and refer almost exclusively to the current portion of the fair value of derivative instruments used to hedge the exchange risk. The item has been assigned a level of discretion equal to 5 .

- Financial assets for derivatives not designated as hedges are valued at 6.3: a level of discretion of 5 has been assigned.

(13) The item "Cash and cash equivalents" has been assigned a level of discretion of 1 . This is in fact the item whose value determination does not require any subjective assessment by the directors. 
Table 4. Determination of QDI liability —Consolidated Financial Statements 2016 (data in millions of euros)

\begin{tabular}{|c|c|c|c|c|c|c|c|}
\hline \multirow[t]{2}{*}{ LIABILITIES DESCRIPTION } & \multicolumn{5}{|c|}{ LEVELS OF DISCRETION } & \multirow[t]{2}{*}{ TOTAL } & \multirow[t]{2}{*}{ Note } \\
\hline & 1 & 2 & 3 & 4 & 5 & & \\
\hline \multicolumn{8}{|l|}{ NON-CURRENT LIABILITIES } \\
\hline Severance indemnities & & & & & 91.8 & 91.8 & (14) \\
\hline Deferred tax liabilities & & 117.5 & & & & 117.5 & (15) \\
\hline Debts and financial liabilities & & $1,003.5$ & & & 0.6 & $1,004.1$ & (16) \\
\hline Provision for risks and charges & & & & & 96.4 & 96.4 & (17) \\
\hline TOTAL NON-CURRENT LIABILITIES & & & & & & $1,309.8$ & \\
\hline \multicolumn{8}{|l|}{ CURRENT LIABILITIES } \\
\hline Payables to banks & & 158.3 & & & & 158.3 & (18) \\
\hline Payables to suppliers & & $1,765.8$ & & & & $1,765.8$ & (19) \\
\hline Provisions for risks and charges & & & & & 154.3 & 154.3 & (20) \\
\hline Tax payables & & 5.2 & & & & 5.2 & (21) \\
\hline Other financial liabilities & & 372.3 & & & 0.4 & 372.7 & (22) \\
\hline Other current liabilities & & 232.8 & & & & 232.8 & (23) \\
\hline TOTAL CURRENT LIABILITIES & & & & & & $2,689.2$ & \\
\hline TOTAL LIABILITIES & & & & & & 3,999 & \\
\hline \% Level of discretion of the total & $0.00 \%$ & $91.41 \%$ & $0.00 \%$ & $0.00 \%$ & $8.59 \%$ & $100.00 \%$ & \\
\hline$Q D I_{l}$ & 2.26 & & & & & & \\
\hline
\end{tabular}

(14) The item "Severance indemnities" was assigned a level of discretion of 5. The explanatory notes show that the value of this item is the result of complex actuarial calculations based on demographic and financial assumptions specific to the company. Therefore, it is considered correct to assign the highest level of discretion.

(15) "Deferred tax liabilities" have been assigned a level of discretion of 2 since they are determined on the basis of the temporary differences between the assets recognised in the financial statements and the corresponding values recognised for tax purposes.

(16) The item "Debts and financial liabilities" consists of amounts of different types:

- Due to banks, an amount equal to 395.7, has been assigned a level of discretion of 2 . These payables are recorded in the financial statements by applying the amortised cost method.

- Bonds payable, an amount equal to 600.3 , has been assigned a level of discretion of 2 . These payable amounts are recorded in the financial statements by applying the amortised cost method based on the internal rate of return.

- $\quad$ Payables to other lenders equal 1.4, and the level of discretion assigned is 2.

- Financial liabilities on derivatives intended for hedging (non-current portion), an amount equal to 0.6, refers to the non-current portion of the fair value of derivative instruments hedging the risk of changes in the interest rate of medium/long-term financial liabilities. The level of discretion assigned is 5 .

- Other financial liabilities, an amount equal to 6.2, has been assigned a level of discretion of 2 .

(17) The item "Provisions for risks and charges" has been assigned a level of discretion of 5, as the company relies on internal inputs that are not observable on the market.

(18) The item "Payables to banks" has been assigned a level of discretion of 2 . These are the current portion of loans and lines of credit.

(19) The item "Payables to suppliers" was assigned a level of discretion equal to 2. Trade payables are recorded at the nominal value that generally approximates the amortised cost.

(20) The item "Provisions for risks and charges" has been assigned a level of discretion of 5 . The decision to assign the maximum level of discretion is determined by the fact that the provisions are recorded at the value representing the best estimate of the amount that the company would pay to extinguish the obligation; in order to do this, the company relies on internal inputs that are not observable on the market.

(21) The item "Tax payables" was assigned a level of discretion of 2 . This item refers to the position vis-à-vis the tax authorities for companies not included in the tax consolidation and the debit positions relating to foreign companies.

(22) The item "Other financial liabilities" consists of the following amounts: 
- Bond loans, an amount equal to 338.9, and payables to other lenders, an amount equal to 33.4 , have both been assigned a level of discretion of 2 (measurement at amortised cost).

- Financial liabilities on non-hedged derivatives, an amount equal to 0.1, and financial liabilities on designated hedging derivatives (cash flow hedges), an amount equal to 0.3 , have both been assigned a level of discretion of 5 .

(23) The item "Other current liabilities" (consisting of payables to social security and welfare institutions, withholdings on labour income, VAT payable, other payables to the tax authorities, advances, payables to others, accrued income and prepaid expenses) was allocated a level of discretion of 2 since the items that compose it are valued primarily at amortised cost or have valuation techniques that fall within this level of discretion.

\section{Results}

Analysisng the results of case study, it can be seen that the $\mathrm{QDI}_{\mathrm{a}}$ is higher than the $\mathrm{QDI}_{\mathrm{l}}$. This is because the valuation of the assets in the financial statements examined reflects (particularly television rights and goodwill) as a very high level of the discretionary assessment granted to managers. In contrast, the discernment of managers was not a major factor in developing the valuation of the majority of the liabilities, resulting in valuations based on more objective evaluation criteria.

Overall, it can be said that most of the data shown in the analysed financial statements are based on assessments with a good degree of objectivity.

The example illustrated here shows how the calculation of QDI for the asset side and QDI for liability side of the balance sheet is characterised by great simplicity, allowing any stakeholder to use it. Moreover, the adoption of the matrix form immediately reveals a clear idea of which items have a greater level of discretion. These items are those that tend to be more volatile and, therefore, may be the subject of greater attention by the budget reader. Finally, the presence of the final row that expresses the percentage "weight" of each column enables a clear understanding of the level of discretion prevalently used by managers in preparing the financial statements. This is very useful data, which allows us to shed light on evaluative discretion, an aspect that has not yet been investigated but that is of great importance.

There is a close connection between the adoption of QDI and Business Ethics. Among the goals of Business Ethics, there is also the facilitation of the correctness of social communications and the minimisation of opportunistic earnings management (EM) practices in the financial statements (Martínez-Ferrero et al., 2016). As shown in the case study, QDI could be a very useful tool to aim this objective. Thanks to QDI, stakeholders can easily identify balance sheet areas with a higher level of evaluative discretion and they can pay more attention to them. For example, considering this case study, a stakeholder will pay attention to analyze the information about television rights and goodwill, because they are quantitatively important balance sheet items with a very high level of subjectivity in their assessment (and this can be understood very clearly thanks to QDI). Consequently, managers are driven to use their flexibility in drawing up the balance sheet in the correct way and they are discouraged from executing opportunistic earnings management practices. Indeed, using QDI, stakeholders could discover EM practices more easily: once higher evaluative discretion balance sheet items are identified (adopting QDI), if information in the explicative note is too general or absent or inconsistent with internal or external economic variables, it could be an indicator of likely opportunistic EM behaviour. The QDI can become a tool to encourage ethics behaviour by managers.

Adopting QDI as voluntary information in the explicative notes of balance sheet improves the quality of financial disclosure. It is in the interests of all stakeholders, the "responsible managers" (Gelb \& Strawser, 2001), but also for the company. Indeed, as outlined by Martínez-Ferrero et al. (2016), improvements in earnings quality lower information asymmetry positively affect the cost of capital (Francis et al., 2005, 2008; Bhattacharya et al., 2003; Blanco et al., 2009), reputation and corporate image (Fombrun et al. 2000; Roychowdhury, 2006).

\section{Discussion and Future Research}

In recent years, the compliance of companies' accounting practices with ethical standards has been intensively placed under the attention of the markets (Martínez-Ferrero et al., 2016); therefore, due to a better reputation in the markets, companies that undertake ethics behaviour enjoy a lower cost of capital procurement.

Companies can also achieve a better reputation through higher quality social communications and particularly by adopting policies to combat opportunistic EM practices that often occur more frequently in the areas of the financial statements that are subject to greater assessment discretion. 
Among the measures that each company could decide to take on voluntarily is that of highlighting the areas subject to greater managerial discretion by the managers: this will enable the stakeholders to monitor these areas, countering the possible phenomena of agent-principal behaviour by the managers.

In this work, the QDI-Quantitative Discretion Index-was presented as a possible voluntary additional disclosure, which allows stakeholders to assess how much of the balance sheet is a consequence of evaluative activity and therefore potentially sensitive to EM activities.

In this sense, for a better interpretation of the financial statements, we intend to offer a new information element consisting of a synthetic index of discretion and a matrix format prospectus, which is able to indicate to the reader of the financial statements the areas subject to greater evaluative discretion.

In this way, each stakeholder can individually assess the composition of the values constituting the financial statements between certain and estimated values and draw their personal information and conclusions from the data examined.

The progress of financial reporting must be a goal for all managers; as highlighted by Gelb and Strawser (2001), the improvement of the financial disclosure is, in effect, a form of the "socially responsible" behaviour of managers.

It should be noted that this work does not aim to build a model able to investigate whether managers use the discretion granted to them in a physiological or pathological way; on the contrary, our research question is to provide further support to business ethics by providing additional balance sheet information to stakeholders.

Possible ideas for future research concern the possibility of not only extending the QDI to the balance sheet but also to the income statement.

Furthermore, for a broader examination of the relationship between the "level of discretion", EM and the implementation of ethical behaviour, future research is encouraged to adopt this indicator to perform statistical surveys on samples of companies.

\section{References}

Acharya, V. V., \& Lambrecht, B. M. (2015). A theory of income smoothing when insiders know more than outsiders. The Review of Financial Studies, 28(9), 2534-2574. https://doi.org/10.1093/rfs/hhv026

Alberici, A., \& Querci, F. (2016). The quality of disclosures on environmental policy: The Profile of financial intermediaries. Corporate Social Responsibility and Environmental Management, 23(5), 283-296. https://doi.org/10.1002/csr.1375

Allen, E. J., Larson, C. R., \& Sloan, R. G. (2013). Accrual reversals, earnings and stock returns. Journal of Accounting and Economics, 56(1), 113-129. https://doi.org/10.1016/j.jacceco.2013.05.002

Altamuro, J., Beatty, A. L., \& Weber, J. (2005). The effects of accelerated revenue recognition on earnings management and earnings informativeness: Evidence from SEC Staff Accounting Bulletin No. 101. The Accounting Review, 80(2), 373-401. https://doi.org/10.2308/accr.2005.80.2.373

Arya, A., Glover, J. C., \& Sunder, S. (2003). Are unmanaged earnings always better for shareholders? Accounting Horizons, 17, 111. https://doi.org/10.2308/acch.2003.17.s-1.111

Badertscher, B. A., Collins, D. W., \& Lys, T. Z. (2012). Discretionary accounting choices and the predictive ability of accruals with respect to future cash flows. Journal of Accounting and Economics, 53(1-2), 330-352. https://doi.org/10.1016/j.jacceco.2011.11.003

Barker, R. (2004). Reporting financial performance. Accounting Horizons, 18(2), 157-172. https://doi.org/10.2308/acch.2004.18.2.157

Barth, M. E. (2018). The Future of Financial Reporting: Insights from Research. Abacus, 54(1), 66-78. https://doi.org/10.1111/abac.12124

Beaudoin, C., Cianci, A., \& Tsakumis, G. (2015). The Impact of CFOs' Incentives and Earnings Management Ethics on their Financial Reporting Decisions: The Mediating Role of Moral Disengagement. Journal of Business Ethics, 128(3), 505-518. https://doi.org/10.1007/s10551-014-2107-x

Bens, D. A., \& Heltzer, W. (2005). The information content and timeliness of fair value accounting: goodwill write-offs before, during and after implementation of SFAS 142. Cahier de recherche, Université de Chicago. https://doi.org/10.2139/ssrn.590345

Bhattacharya, U., Daouk, H., \& Welker, M. (2003). The world price of earnings opacity. The Accounting Review, 
78(3), 641-678. https://doi.org/10.2308/accr.2003.78.3.641

Binder, J. (1998). The event study methodology since 1969. Review of Quantitative Finance and Accounting, 11(2), 111-137. https://doi.org/10.1023/A:1008295500105

Blanco Peláez, B., García Lara, J. M., \& Tribó Giné, J. A. (2010). The Complementarity between segment disclosure and earnings quality, and its effect on cost of capital. In 32nd Annual Congress of the European

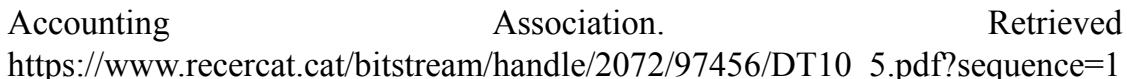

Bonacchi, M., Cipollini, F., \& Zarowin, P. (2018). Parents' use of subsidiaries to "push down" earnings management: Evidence from Italy. Contemporary Accounting Research, 35(3), 1332-1362. https://doi.org/10.1111/1911-3846.12330

Bosse, D. A., \& Phillips, R. A. (2016). Agency theory and bounded self-interest. Academy of Management Review, 4l(2), 276-297. https://doi.org/10.5465/amr.2013.0420

Burgstahler, D., \& Dichev, I. (1997). Earnings management to avoid earnings decreases and losses. Journal of Accounting and Economics, 24(1), 99-126. https://doi.org/10.1016/S0165-4101(97)00017-7

Burgstahler, D., \& Eames, M. (2006). Management of earnings and analysts' forecasts to achieve zero and small positive earnings surprises. Journal of Business Finance \& Accounting, 33(5-6), 633-652. https://doi.org/10.1111/j.1468-5957.2006.00630.x

Carroll, A., \& Buchholtz, A. (2014). Business and society: Ethics, sustainability, and stakeholder management. Nelson Education.

Chih, H. L., Shen, C. H., \& Kang, F. C. (2008). Corporate social responsibility, investor protection, and earnings management: Some international evidence. Journal of Business Ethics, 79(1-2), 179-198. https://doi.org/10.1007/s10551-007-9383-7

Dalton, D. R., Hitt, M. A., Certo, S. T., \& Dalton, C. M. (2007). 1 The Fundamental Agency Problem and Its Mitigation: Independence, Equity, and the Market for Corporate Control. The Academy of Management Annals, 1(1), 1-64. https://doi.org/10.1080/078559806

Das, S., Hong, K., \& Kim, K. (2013). Earnings smoothing, cash flow volatility, and CEO cash bonus. Financial Review, 48(1), 123-150. https://doi.org/10.1111/j.1540-6288.2012.00349.x

DeAngelo, L. E. (1986). Accounting numbers as market valuation substitutes: A study of management buyouts of public stockholders. Accounting Review, 400-420. https://www.jstor.org/stable/247149

Dechow, P. M., Hutton, A. P., Kim, J. H., \& Sloan, R. G. (2012). Detecting earnings management: A new approach. Journal of Accounting Research, 50(2), 275-334. https://doi.org/10.1111/j.1475-679X.2012.00449.x

Dechow, P. M., Sloan, R. G., \& Sweeney, A. P. (1995). Detecting earnings management. Accounting Review, 193-225. https://www.jstor.org/stable/248303

Deegan, C., \& Gordon, B. (1996). A study of the environmental disclosure practices of Australian corporations. Accounting and Business Research, 26(3), 187-199. https://doi.org/10.1080/00014788.1996.9729510

Degeorge, F., Patel, J., \& Zeckhauser, R. (1999). Earnings management to exceed thresholds. The Journal of Business, 72(1), 1-33. https://doi.org/10.1086/209601

Demski, J. S. (1998). Performance measure manipulation. Contemporary Accounting Research, 15(3), 261-285. https://doi.org/10.1111/j.1911-3846.1998.tb00560.x

Detzen, D., \& Zülch, H. (2012). Executive compensation and goodwill recognition under IFRS: Evidence from European mergers. Journal of International Accounting, Auditing and Taxation, 21(2), 106-126. https://doi.org/10.1016/j.intaccaudtax.2012.07.002

Dhaliwal, D. S., Li, O. Z., Tsang, A., \& Yang, Y. G. (2011). Voluntary nonfinancial disclosure and the cost of equity capital: The initiation of corporate social responsibility reporting. The Accounting Review, 86(1), 59-100. https://doi.org/10.2308/accr.00000005

Dhaliwal, D., Li, O. Z., Tsang, A., \& Yang, Y. G. (2014). Corporate social responsibility disclosure and the cost of equity capital: The roles of stakeholder orientation and financial transparency. Journal of Accounting and Public Policy, 33(4), 328-355. https://doi.org/10.1016/j.jaccpubpol.2014.04.006

Dolley, J. C. (1933). Characteristics and procedure of common stock split-ups. Harvard Business Review, 11(3), 
$316-326$.

Eisenhardt, K. M. (1985). Control: Organizational and economic approaches. Management Science, 31(2), 134-149. https://doi.org/10.1287/mnsc.31.2.134

Eisenhardt, K. M. (1988). Agency-and institutional-theory explanations: The case of retail sales compensation. Academy of Management Journal, 31(3), 488-511. https://doi.org/10.5465/256457

Eisenhardt, K. M. (1989). Agency theory: An assessment and review. Academy of Management Review, 14(1), 57-74. https://doi.org/10.5465/amr.1989.4279003

Elias, R. Z. (2002). Determinants of earnings management ethics among accountants. Journal of Business Ethics, 40(1), 33-45. https://doi.org/10.1023/A:1019956821253

Fama, E. F. (1980). Agency problems and the theory of the firm. Journal of Political Economy, 88(2), $288-307$. https://doi.org/10.1086/260866

Fama, E. F., Fisher, L., Jensen, M. C., \& Roll, R. (1969). The adjustment of stock prices to new information. International Economic Review, 10(1), 1-21. https://doi.org/10.2307/2525569

FASB. (2017). Project Update-Disclosure Framework. Retrieved from http://www.fasb.org/jsp/FASB/FASBContent_C/ProjectUpdatePage\&cid=1176156344894

Fombrun, C. J., Gardberg, N. A., \& Barnett, M. L. (2000). Opportunity platforms and safety nets: Corporate citizenship and reputational risk. Business and Society Review, 105(1), 85-106. https://doi.org/10.1111/0045-3609.00066

Francis, J., Huang, A. H., Rajgopal, S., \& Zang, A. Y. (2008). CEO reputation and earnings quality. Contemporary Accounting Research, 25(1), 109-147. https://doi.org/10.1506/car.25.1.4

Francis, J., LaFond, R., Olsson, P., \& Schipper, K. (2005). The market pricing of accruals quality. Journal of Accounting and Economics, 39(2), 295-327. https://doi.org/10.1016/j.jacceco.2004.06.003

Frank, M. M., Lynch, L. J., Rego, S. O., \& Zhao, R. (2018). Are corporate risk-taking practices indicative of aggressive reporting practices? The Journal of the American Taxation Association, 40(1), 31-55. https://doi.org/10.2308/atax-51809

Freeman, R. E. (1984). Strategic Management: A Stakeholder Approach. Pitman, Boston, MA.

Freeman, R. E. (1994). The politics of stakeholder theory: Some future directions. Business Ethics Quarterly, 409-421. https://doi.org/10.2307/3857340

Freeman, R. E., Harrison, J. S., Wicks, A. C., Parmar, B. L., \& De Colle, S. (2010). Stakeholder theory: The state of the art. Cambridge University Press. https://doi.org/10.1017/CBO9780511815768

Friedman, M. (1970). The Social Responsibility of Business is to make profit. New York Times Magazine, 13.

Gaver, J. J., Gaver, K. M., \& Austin, J. R. (1995). Additional evidence on bonus plans and income management. Journal of Accounting and Economics, 19(1), 3-28. https://doi.org/10.1016/0165-4101(94)00358-C

Gelb, D. S., \& Strawser, J. A. (2001). Corporate social responsibility and financial disclosures: An alternative explanation for increased disclosure. Journal of Business Ethics, 33(1), 1-13. https://doi.org/10.1023/A:1011941212444

Gervasio, D., \& Montani, D. (2013). IFRS Subjectivity: the other side of the coin. Universal Journal of Accounting and Finance, 1(2), 58-69. http://hdl.handle.net/10446/29180

Gong, G., Xu, S., \& Gong, X. (2018). On the value of corporate social responsibility disclosure: An empirical investigation of corporate bond issues in China. Journal of Business Ethics, 150(1), $227-258$. https://doi.org/10.1007/s10551-016-3193-8

Gowthorpe, C., \& Amat, O. (2005). Creative accounting: some ethical issues of macro-and micro-manipulation. Journal of Business Ethics, 57(1), 55-64. https://doi.org/10.1007/s10551-004-3822-5

Greenfield, A. C., Norman, C. S., \& Wier, B. (2008). The effect of ethical orientation and professional commitment on earnings management behavior. Journal of Business Ethics, 83(3), 419-434. https://doi.org/10.1007/s10551-007-9629-4

Guay, W. R., Kothari, S. P., \& Watts, R. L. (1996). A market-based evaluation of discretionary accrual models. Journal of Accounting Research, 34, 83-105. https://doi.org/10.2307/2491427

Guidry, F., Leone, A. J., \& Rock, S. (1999). Earnings-based bonus plans and earnings management by 
business-unit managers1. Journal of Accounting and Economics, 26(1-3), 113-142. https://doi.org/10.1016/S0165-4101(98)00037-8

Guthrie, K., Kwon, I., \& Sokolowsky, J. (2017). What Does CEOs' Pay-for-Performance Reveal About Shareholders' Attitude Toward Earnings Overstatements? Journal of Business Ethics, 146(2), 419-450. https://doi.org/10.1007/s10551-015-2891-y

Harrison, J. S., \& Wicks, A. C. (2013). Stakeholder theory, value, and firm performance. Business Ethics Quarterly, 23(1), 97-124. https://doi.org/10.5840/beq20132314

Healy, P. M. (1985). The effect of bonus schemes on accounting decisions. Journal of Accounting and Economics, 7(1-3), 85-107. https://doi.org/10.1016/0165-4101(85)90029-1

Healy, P. M., \& Palepu, K. G. (1993). The effect of firms' financial disclosure strategies on stock prices. Accounting Horizons, 7(1), 1.

Healy, P. M., \& Wahlen, J. M. (1999). A review of the earnings management literature and its implications for standard setting. Accounting Horizons, 13(4), 365-383. https://doi.org/10.2308/acch.1999.13.4.365

Heckerman, D. G. (1975). Motivating managers to make investment decisions. Journal of Financial Economics, 2(3), 273-292. https://doi.org/10.1016/0304-405X(75)90016-1

Hill, C. W., \& Jones, T. M. (1992). Stakeholder-agency theory. Journal of Management Studies, 29(2), 131-154. https://doi.org/10.1111/j.1467-6486.1992.tb00657.x

Holthausen, R. W. (1990). Accounting method choice: Opportunistic behavior, efficient contracting, and information perspectives. Journal of Accounting and Economics, 12(1-3), 207-218. https://doi.org/10.1016/0165-4101(90)90047-8

Hong, Y., \& Andersen, M. (2011). The Relationship Between Corporate Social Responsibility and Earnings Management: An Exploratory Study. Journal of Business Ethics, 104(4), 461-471. https://doi.org/10.1007/s10551-011-0921-y

Hooghiemstra, R. (2000). Corporate communication and impression management-new perspectives why companies engage in corporate social reporting. Journal of Business Ethics, 27(1-2), 55-68. https://doi.org/10.1023/A:1006400707757

IAS plus. (2006). IASB AgendaProject: ReportingComprehensive Income (Performance reporting). Retrieved October 10, 2006, from http://www.iasplus.com/agenda/perform.htm

IASB. (2001). Framework for the Preparation and Presentation of Financial Statements.

IASB. (2003). Performance Reporting Project: Summary Information for Visit Subjects.

IASB. (2011). IFRS 13 - Fair Value Measurement.

IASB. (2012). IAS 1 - Presentation of Financial Statement. London: International Accounting Standard Board.

Jensen, M. C., \& Meckling, W. H. (1976). Theory of the firm: Managerial behavior, agency costs and ownership structure. Journal of Financial Economics, 3(4), 305-360. https://doi.org/10.1007/978-94-009-9257-3_8

Jin, J., Kanagaretnam, K., \& Lobo, G. J. (2018). Discretion in bank loan loss allowance, risk taking and earnings management. Accounting \& Finance, 58(1), 171-193. https://doi.org/10.1111/acfi.12210

Jiraporn, P., Miller, G. A., Yoon, S. S., \& Kim, Y. S. (2008). Is earnings management opportunistic or beneficial? An agency theory perspective. International Review of Financial Analysis, 17(3), 622-634. https://doi.org/10.1016/j.irfa.2006.10.005

Johnson, E. N., Fleischman, G., Valentine, S., \& Walker, K. B. (2011). Managers' ethical evaluations of earnings management and its consequences. Contemporary Accounting Research, forthcoming. https://doi.org/10.1111/j.1911-3846.2011.01135.x

Jones, J. J. (1991). Earnings management during import relief investigations. Journal of Accounting Research, 29(2), 193-228. https://doi.org/10.2307/2491047

Jordan, C. E., \& Clark, S. J. (2004). Big bath earnings management: the case of goodwill impairment under SFAS No. 142. Journal of Applied Business Research, 20(2), 63-70. https://doi.org/10.19030/jabr.v20i2.2206

Kanagaretnam, K., Lobo, G. J., \& Yang, D. H. (2005). Determinants of signaling by banks through loan loss provisions. Journal of Business Research, 58(3), 312-320. https://doi.org/10.1016/j.jbusres.2003.06.002 
Katmon, N., \& Al Farooque, O. (2017). Exploring the impact of internal corporate governance on the relation between disclosure quality and earnings management in the UK listed companies. Journal of Business Ethics, 142(2), 345-367. https://doi.org/10.1007/s10551-015-2752-8

Khurana, I. K., Pereira, R., \& Zhang, E. (2018). Is real earnings smoothing harmful? Evidence from firm—specific stock price crash risk. Contemporary Accounting Research, 35(1), 558-587. https://doi.org/10.1111/1911-3846.12353

Kolk, A. (2003). Trends in sustainability reporting by the Fortune Global 250. Business Strategy and the Environment, 12(5), 279-291. https://doi.org/10.1002/bse.370

Kothari, S. P., Leone, A. J., \& Wasley, C. E. (2005). Performance matched discretionary accrual measures. Journal of Accounting and Economics, 39(1), 163-197. https://doi.org/10.1016/j.jacceco.2004.11.002

Lapointe-Antunes, P., Cormier, D., \& Magnan, M. (2008). Equity recognition of mandatory accounting changes: The case of transitional goodwill impairment losses. Canadian Journal of Administrative Sciences, 25(1), 37-54. https://doi.org/10.1002/cjas.41

Leuz, C., Nanda, D., \& Wysocki, P. D. (2003). Earnings management and investor protection: an international $\begin{array}{llll}\text { comparison. Journal of Financial 505-527. } & \text { Economics, }\end{array}$ https://doi.org/10.1016/S0304-405X(03)00121-1

Li, L., \& Kuo, C. S. (2017). CEO equity compensation and earnings management: The role of growth opportunities. Finance Research Letters, 20, 289-295. https://doi.org/10.1016/j.frl.2016.10.013

Lima Crisóstomo, V., de Souza Freire, F., \& Cortes de Vasconcellos, F. (2011). Corporate social responsibility, firm value and financial performance in Brazil. Social Responsibility Journal, 7(2), 295-309. https://doi.org/10.1108/17471111111141549

Mahadeo, J. D., Oogarah-Hanuman, V., \& Soobaroyen, T. (2011, September). Changes in social and environmental reporting practices in an emerging economy (2004-2007): Exploring the relevance of stakeholder and legitimacy theories. Accounting Forum, 35(3), 158-175. Taylor \& Francis. https://doi.org/10.1016/j.accfor.2011.06.005

Martin, G. P., Wiseman, R. M., \& Gomez-Mejia, L. R. (2019). The interactive effect of monitoring and incentive alignment on agency costs. Journal of Management, 45(2), 701-727. https://doi.org/10.1177/0149206316678453

Martínez-Ferrero, J., Banerjee, S., \& García-Sánchez, I. M. (2016). Corporate social responsibility as a strategic shield against costs of earnings management practices. Journal of Business Ethics, 133(2), 305-324. https://doi.org/10.1007/s10551-014-2399-x

Martínez-Ferrero, J., Garcia-Sanchez, I. M., \& Cuadrado-Ballesteros, B. (2015). Effect of financial reporting quality on sustainability information disclosure. Corporate Social Responsibility and Environmental Management, 22(1), 45-64. https://doi.org/10.1002/csr.1330

McNichols, M. (2002). The Quality of Accruals and Earnings: The Role of Accrual Estimation Errors: Discussion. The Accounting Review, 77, 61-69. https://doi.org/10.2308/accr.2002.77.s-1.61

McNichols, M., \& Wilson, G. P. (1988). Evidence of earnings management from the provision for bad debts. Journal of Accounting Research, 1-31. https://doi.org/10.2307/2491176

McWilliams, A., \& Siegel, D. (2001). Corporate social responsibility: A theory of the firm perspective. Academy of Management Review, 26(1), 117-127. https://doi.org/10.5465/amr.2001.4011987

Merchant, K. A., \& Rockness, J. (1994). The ethics of managing earnings: An empirical investigation. Journal of Accounting and Public Policy, 13(1), 79-94. https://doi.org/10.1016/0278-4254(94)90013-2

Miller, J. S. (2009). Opportunistic disclosures of earnings forecasts and non-GAAP earnings measures. Journal of Business Ethics, 89(1), 3-10. https://doi.org/10.1007/s10551-008-9903-0

Mindak, M. P., Sen, P. K., \& Stephan, J. (2016). Beating threshold targets with earnings management. Review of Accounting and Finance, 15(2), 198-221. https://doi.org/10.1108/RAF-04-2015-0057

Nieken, P., \& Sliwka, D. (2015). Management Changes, Reputation, and "Big Bath"-Earnings Management. Journal of Economics \& Management Strategy, 24(3), 501-522. https://doi.org/10.1111/jems.12101

Orlitzky, M., Schmidt, F. L., \& Rynes, S. L. (2003). Corporate social and financial performance: A meta-analysis. Organization Studies, 24(3), 403-441. https://doi.org/10.1177/0170840603024003910 
Pepper, A., \& Gore, J. (2015). Behavioral agency theory: New foundations for theorizing about executive compensation. Journal of Management, 41(4), 1045-1068. https://doi.org/10.1177/0149206312461054

Platonova, E., Asutay, M., Dixon, R., \& Mohammad, S. (2018). The impact of corporate social responsibility disclosure on financial performance: Evidence from the GCC Islamic banking sector. Journal of Business Ethics, 151(2), 451-471. https://doi.org/10.1007/s10551-016-3229-0

Ramanna, K. (2008). The implications of unverifiable fair-value accounting: Evidence from the political economy of goodwill accounting. Journal of Accounting and Economics, 45(2-3), 253-281. https://doi.org/10.1016/j.jacceco.2007.11.006

Reverte, C. (2012). The impact of better corporate social responsibility disclosure on the cost of equity capital. Corporate Social Responsibility and Environmental Management, 19(5), 253-272. https://doi.org/10.1002/csr.273

Ross, S. A. (1973). The economic theory of agency: The principal's problem. The American Economic Review, 63(2), 134-139. https://www.jstor.org/stable/1817064

Roychowdhury, S. (2006). Earnings management through real activities manipulation. Journal of Accounting and Economics, 42(3), 335-370. https://doi.org/10.1016/j.jacceco.2006.01.002

Schipper, K. (1989). Commentary on earnings management. Accounting Horizons, 3(4), 91-102.

Shafer, W. E. (2015). Ethical climate, social responsibility, and earnings management. Journal of Business Ethics, 126(1), 43-60. https://doi.org/10.1007/s10551-013-1989-3

Shankman, N. A. (1999). Reframing the debate between agency and stakeholder theories of the firm. Journal of Business Ethics, 19(4), 319-334. https://doi.org/10.1023/A:1005880031427

Shi, W., Connelly, B. L., \& Hoskisson, R. E. (2017). External corporate governance and financial fraud: cognitive evaluation theory insights on agency theory prescriptions. Strategic Management Journal, 38(6), 1268-1286. https://doi.org/10.1002/smj.2560

Standards Advisory Council. (2006). Minutes of the Meeting of the Standards Advisory Council held in London on 9 and 10 November 2006.

Stanwick, P. A., \& Stanwick, S. D. (1998). The relationship between corporate social performance, and organizational size, financial performance, and environmental performance: An empirical examination. Journal of Business Ethics, 17(2), 195-204. https://doi.org/10.1023/A:1005784421547

Subramanyam, K. R. (1996). The pricing of discretionary accruals. Journal of Accounting and Economics, 22(1-3), 249-281. https://doi.org/10.1016/S0165-4101(96)00434-X

Tarca, A., Brown, P. R., Hancock, P., Woodliff, D. R., Bradbury, M. E., \& van Zijl, T. (2007). The Matrix Format Income Statement: A Case Study about Earnings Management and Reporting Financial Performance. Issues in Accounting Education, 22(4), 607-623. https://doi.org/10.2308/iace.2007.22.4.607

Tarca, A., Hancock, P., Woodliff, D., Brown, P., Bradbury, M., \& Van Zijl, T. (2008). Identifying decision useful information with the matrix format income statement. Journal of International Financial Management \& Accounting, 19(2), 184-217. https://doi.org/10.1111/j.1467-646X.2008.01021.x

Vladu, A. B., Amat, O., \& Cuzdriorean, D. D. (2017). Truthfulness in accounting: How to discriminate accounting manipulators from non-manipulators. Journal of Business Ethics, 140(4), 633-648. https://doi.org/10.1007/s10551-016-3048-3

Watts, R., \& Zimmerman, J. (1986). Positive accounting theory. Englewood Cliffs, NJ: Prentice-Hall.

\section{Copyrights}

Copyright for this article is retained by the author, with first publication rights granted to the journal.

This is an open-access article distributed under the terms and conditions of the Creative Commons Attribution license (http://creativecommons.org/licenses/by/4.0/). 